\title{
Architectural Metaphors of Knowledge: The Mundaneum Designs of Maurice Heymans, Paul Otlet, and Le Corbusier
}

\author{
Wouter VAN Acker
}

\begin{abstract}
The author discusses the architectural plans of the Mundaneum made in the 1930s by the Belgian modernist architect Maurice Heymans in the footsteps of Le Corbusier and in collaboration with Paul Otlet. The Mundaneum was the utopian concept of a world center for the accumulation, organization, and dissemination of knowledge, invented by the visionary encyclopedist and internationalist Paul Otlet. In Heymans's architecture, a complex architectural metaphor is created for the Mundaneum, conveying its hidden meaning as a center of initiation into synthesized knowledge. In particular, this article deconstructs the metaphorical architectural complex designed by Heymans and focuses on how the architectural spaces as designed by Heymans are structured in analogy to schemes for the organization of knowledge made by Otlet. In three different designs of the Mundaneum, the analogy is studied between, on the one hand, the architectural structure (designed by Heymans) and, on the other hand, the structure of the cosmology, the book Monde, and the vision of knowledge dissemination as invented by Otlet. The article argues that the analogies between the organization of architectural space and knowledge, as expressed in the drawings of Heymans and Otlet, are elaborated by means of a mode of visual thinking that is parallel to and rooted in the art of memory and utopian imagination.
\end{abstract}

\section{In the Footsteps of Le Corbusier}

In 1935, the Belgian modernist architect Maurice Heymans (1909-1991) elaborated numerous highly detailed drawings of the Mundaneum as conceived by his compatriot, the documentalist and utopian internationalist, Paul Otlet (1868-1944). The Mundaneum was Otlet's expanded project 
of what he called "Offices of Documentation," which he defined as a new kind of information service that would supplement and eventually absorb libraries. Otlet had strongly criticized their conservative approach to information services and their outmoded methods of classification and cataloging (Rayward, 1997, p. 295). The Mundaneum was intended to be a scientific, documentary, educational, and social institution that would explain the world in all its parts and, by doing so, would help to bring peace to the world. Otlet also applied the term to the complex of institutions that he and his colleague, the prominent Belgian socialist and Nobel Peace Prize laureate Henri La Fontaine, had directed and had brought together in the Palais Mondial (World Palace) in the left wing of the Palais du Cinquantenaire in Brussels.

Heymans is especially known for his achievements as the head of the Urbanist Department in the Belgian Congo after World War II. But, in 1935, when he designed the Mundaneum for Otlet, he was still at the beginning of his career. ${ }^{1}$ He had graduated in 1930 from the Institut Supérieur des Arts Décoratifs de l'Etat (ISAD) in La Cambre-the "Belgian Bauhaus," as Jacques Aron calls it (Aron, 1982) — and had interned at the architectural offices of the leading Belgian architects Victor Bourgeois (1897-1962), Gaston Brunfaut (1894-1974), Jean-Jules Eggericx (1884-1963), and Raphaël Verwilghen (1885-1963). He was a member of the Belgian CIAM group (Congrès Internationaux d'Architecture Moderne) and published regularly in journals such as L'Époque and La Cité. In 1932, he won the competition for an urbanization plan of the Belgian town Termonde.

Heymans translated Otlet's utopian vision of the Mundaneum into architecture, and therefore followed in the footsteps of the Swiss architect Le Corbusier - the leading avant-gardist of the new machine esthetics in modern architecture-who had drafted detailed plans for a Mundaneum near Geneva in 1928. Otlet and Le Corbusier had published a booklet in 1928 with the plans for a center of information, science, and education to complement the political League of Nations. The most pronounced building of the Intellectual Centre of the Mundaneum was the World Museum, which had the form of a spiraling pyramid that reconfigured Otlet's International Museum in Brussels (fig. 1). The pyramidal museum gave the impression of a sort of a sacred temple complex dating from Babylonian or Assyrian times. In particular, the seven-tiered, ziggurat-like form of the World Museum resembled formally the observatory of the palace of Khorsabad, with which we know Le Corbusier was familiar. ${ }^{2}$

The publication of the plans of the Mundaneum triggered fierce reactions by contemporary architectural critics regarding the historicist traits and academic tendencies of the Mundaneum, which, in their eyes, ran counter to the functionalist principles of modernist architecture of which Le Corbusier in particular was considered to be one of the founding fathers. Karel Teige drew a bead in the architectural journal Stabva 


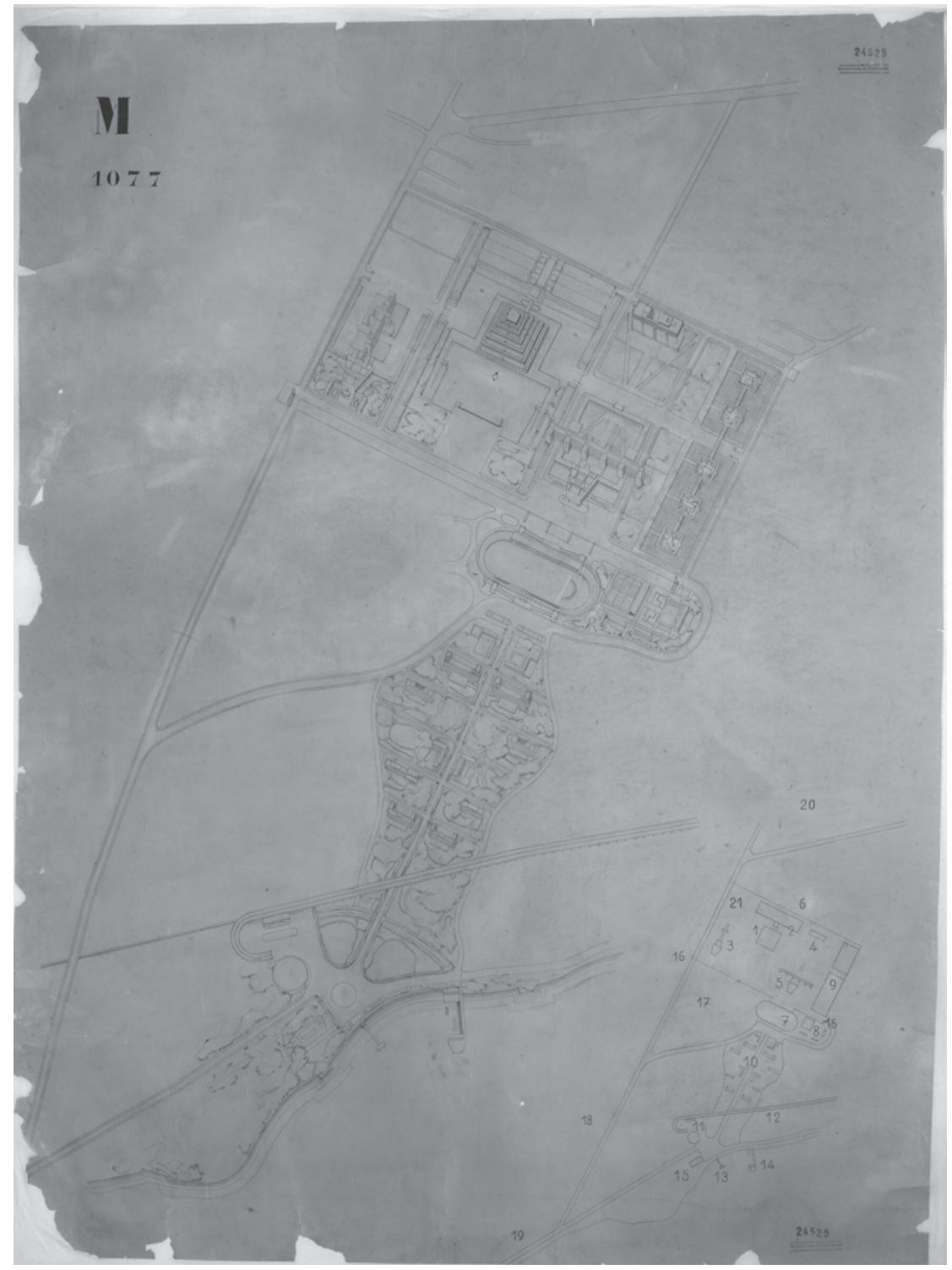

Figure 1. Le Corbusier, Perspective of the Mundaneum (1928.08) (Fondation Le Corbusier, Paris [FLC], fonds Mundaneum FLC - SABAM Belgium 2012). 
in September 1929 on the historical reminiscences of the Mundaneum and the estheticizing, nonfunctional principles of Le Corbusier's work. He admonished Le Corbusier that, through his reluctance to abandon monumentality, he, of all people, had taken the perilous road toward academicism (Teige, 1929 as reproduced in Hays, 1974). ${ }^{3}$ El Lissitzky made a similar critique of the Mundaneum in Marxist terms in the journal Bauindustrie (Lissitzky, 1928). In an essay, "Idole und Idolverehrer," Lissitzky focused on the "pseudo-functionalism" of Le Corbusier, against which the Soviet idolaters amid the constructivist and functionalist movements should be on their guard.

In a long 1933 essay, "In Defense of Architecture," Le Corbusier answered these accusations of academicism, historicist formalism, and religious symbolism that were being made in regard to his design for the Mundaneum (as reproduced in Hays, 1974, pp. 598-614). Patiently, he built up his counterattack against the value of Sachlickheit, or functional directness of expression, on the basis of which Teige, Lissitizky, Mart Stam, and Hannes Meyer were building a front against Le Corbusier, starting from a statement made by Meyer, and quoted by Teige, that "all things in this world are a product of the formula: function times economics" (as reproduced in Hays, 1974, p. 599). In his defense, Le Corbusier directly addressed Teige and told him that in his opinion, esthetics was a fundamental human function and that he therefore opposed Sachlichkeit, or the logic of economic functionality as the sole foundation of modern architecture. Although the Mundaneum was "only a provisional image destined, through its iconography, to work its way into the minds of those who had the means or interest to occupy themselves with it," each building type, Le Corbusier assured us, was "rigorously appropriate to each specific function" (Hays, 1974, p. 608) ${ }^{4}$ Le Corbusier then responded to the central issue in the Mundaneum design that Teige and Lissitzsky objected to, namely, that the Sacrarium in the World Museum revealed that the World Museum was not a museum but, rather, a sort of "sanctuary" and that the pyramidal form that is reminiscent of Babylonian or Assyrian temples expressed this sacred function in a classical monumental fashion. In the same nuanced manner, Le Corbusier argued that the functionality of modern architecture did not exclude it from having a spiritual dimension. The Museum of Human Creation had the shape of a spiraling pyramid to respond to "the absolute continuity of events in history, and the Sacrarium was designed in such a way as to show how great geniuses have, in their time, incarnated the general current of ideas and have convulsed the world. For new things have not convulsed the world, new ideas have: the things being merely the manifestation of ideas" (Hays, 1974, p. $605)$. In reaction to the supposed sacred function of the World Museum, Le Corbusier referred to and defended the "organizational efforts" of Paul Otlet, whom he described as "one of those ardent youths with grey 
hair," "visionaries," and "organizers of ideas" whose "intellectual awakening dates from 1870s" (Hays, 1974, pp. 605-607). Otlet had thought, Le Corbusier said, that

Thus, after the attempts of practical adjustment of the International Labour Office and the League of Nations, it was necessary to go back to the source: we have gone back to what dominates the great balance of the world, pure idea, pure thought. This is the conception of Paul Otlet, of Brussels, the brilliant promoter of the Cité Mondiale. Hence, a new spiritual dimension in architecture is called for. (Le Corbusier 1960, p. 218)

In the same way that Eiffel had made the Eiffel Tower as a "temple to calculation," Le Corbusier stated, he had intended to show with the Mundaneum that architecture is "a manifestation of order."

In 1933, Le Corbusier included a reduced and restructured version of the Mundaneum in his submission for the international town-planning competition for the extension of Antwerp into the left bank of the great bend of the river Scheldt, a proposal that he elaborated in collaboration with Otlet, Huib Hoste (1881-1957), and Fé Loquet. But besides the team of Le Corbusier, at least five other teams had included a Mundaneum or a Cité Mondiale. Among them, there was the team of Maurice Heymans and Emile Henvaux (1903-1991). From a critical review that Victor Bourgeois wrote about the competition and a conference in 1933 organized by the Société Belge des Urbanistes et Architectes Modernistes (SBUAM), it becomes clear that these different teams included a Cité Mondiale in their project as a visual statement that communicated the idea that the development of this part of Antwerp had to be studied in a larger regional, national, and, last but not least, global perspective (Bourgeois, 1933) rather than simply as a local phenomenon. Heymans certainly believed that the development of the left bank had to be considered within the socioeconomic context of the entire region of Antwerp. There was only one solution to achieving this: "to create an independent city and to find a reason for its existence. This could be found in the Mundaneum for example; or in the creation of an industrial city" (Heymans, 1933). He saw the Mundaneum with its scientific and administrative institutions as part of a program that could provide the new city with sufficient economic strength to function as an independent city.

In the aftermath of the competition, a more personal collaboration between Otlet and Heymans began in October 1934 when Heymans wrote Otlet and begged him to help him prepare an article on urbanism for the architectural journal L'Epoque. After praising Otlet's "special expertise in the field of urbanism"-implicitly referring to his role as the founding father of the Belgian bathing resort Westend, his involvement in the International Union of Local Authorities, and the urban museum concept called "the Urbaneum" that he had launched with Victor Bourgeois 
in 1931-Heymans asked for an appointment and promised "to break a lance" for the Mundaneum in reward for his services rendered. ${ }^{5}$ Otlet's influence was noticeable in Heymans's article in the way Heymans defined urbanism in a sociological and holistic manner as "a tool resulting from the activity which sociology unfolds to reach its goals" (1934, p. 62). The title of Otlet's article, "Sociology and Urbanism" (1934), which followed that of Heymans in L'Epoque, suggests what Heymans was hoping for. In return for Otlet's help with the article, Heymans started to make detailed drawings of the Mundaneum. In the end, during the period between 1934 and 1938, he would provide Otlet with numerous drawings, sketches, and highly elaborate plans of the Mundaneum and other concepts of Otlet about the organization of knowledge.

The collaborative Mundaneum designs by the encyclopedist and the architect, Otlet and Heymans, deserve special attention, given the interest in Otlet as some sort of visionary thinker of the information society, the recognition of Heymans as one of the most important urban planners in Belgium in his time, and their relevance in relation to the debate on the Mundaneum design of Le Corbusier as outlined earlier. While the plans of Le Corbusier have been the object of a number of studies in architectural history (Gresleri \& Matteoni, 1982; Courtiau, 1987), the plans of Heymans, which are as detailed as those of Le Corbusier, have not yet been studied.

Heymans's plans of the Mundaneum seemed to have garnered little public attention. They were shown in various small exhibitions, such as in an exhibition organized in 1935 on the occasion of a conference-le Congrès Permanent des Associations de Belgique-organized by Otlet in a hall on the grounds of Heysel Park in Brussels where the Universal Exhibition of 1935 was being held. One reason why Heymans's plans might have received so little attention is that he did not address a political reality, in contrast to the plan of Le Corbusier, which criticized the League of Nations establishment in Geneva for not including cultural internationalism in its program. Nevertheless, the Mundaneum designs of Heymans deserve detailed analysis for the fascinating manner in which they explore the analogy between the organization of knowledge and the organization of architectural space.

This article analyzes the exploration of that analogy in three different designs of the Mundaneum by Heymans. The next section of this article describes how Heymans, in his first Mundaneum building, translated into architecture the structure of Otlet's cosmology. The second section discusses in depth the way in which Heymans visualized in his second Mundaneum design the architectural spaces of various kinds from chapters of Otlet's book Monde. In the last section of this article, I explore how Heymans conveyed with architectural means Otlet's ideas about the geography of knowledge distribution. 


\section{The First Mundaneum Design of Maurice Heymans}

The Mundaneum debate, which attracted much attention in the architectural circles around 1930, must have been an important motive for Heymans to spend so much time in elaborating his version of the Mundaneum. In the footsteps of Le Corbusier, Heymans used an architectural language that was at first sight congruent with "the neutrality of rigour" in the German modernist idiom of the "Neue Sachlichkeit" or the Dutch "Nieuwe Zakelijkheid" (sometimes translated into English as "new objectivity") but that at the same time distorted that language in the way it incorporated an important degree of spiritual symbolism. Like artists such as Wassily Kandinsky, Piet Mondrian, or Kazimir Malevich, Heymans explored in his Mundaneum compositions abstract geometrical forms that were not purely formal but also showed an interest in the occult (Welsh, 1986, p. 64).

The first results of Heymans's quest for the appropriate symbolic abstraction for the Mundaneum are shown in a schematic layout made in January 1935 (fig. 2). Adjusting symbolic to functionalist concerns, he organized the Mundaneum by means of three structures. First, four exhibition rooms arranged in the form of a diagonal cross dealt with the "relative values" of the universe: nature (1.1.), man (1.2.), society (1.3.), and divinity (1.4.). At the intersection of the four arms of the cross, Heymans placed a room that he called in a preparatory sketch the "Pantheon of Humanity" and that contained a monument for the idea of "total synthesis." Second, a circular outside corridor, surrounded by a "peristylium," contained an exhibition that shed light on the sequence of civilizations. Its circular structure symbolized the idea of "evolution" and the "climbing walk of Humanity." The intermediate spaces between the surrounding corridor and the diagonal cross were filled with a library and offices (on the left), a conference room (on the right), and four exhibition rooms that discussed the Continents (2.1.), the Nations (2.2.), the League of Nations (2.3.), and the Cité Mondiale (2.4.). These two structures were completed by a third structure: a central axis consisting of an entrance hall that introduced the universe in its different aspects, flanked by a planetarium and a clock ("horloge zimmer") and followed by a room containing a giant terrestrial globe. The entrance was positioned again in a symbolic manner. Heymans situated the entrance between the rooms attributed to "Nature" and "Divinity" to emphasize the Mundaneum's "impartiality concerning the finalist convictions of Man."

By March 1935, Heymans had elaborated the previous schematic design of the Mundaneum into a first complete virtual or "paper" building with detailed sections, floor plans, and perspectives. The general plan (fig. 3) shows that the building now had a park around it that included pavilions, laboratories, and monuments allocated to the different disciplines that pertain to Otlet's four ontological categories (nature, man, society, 


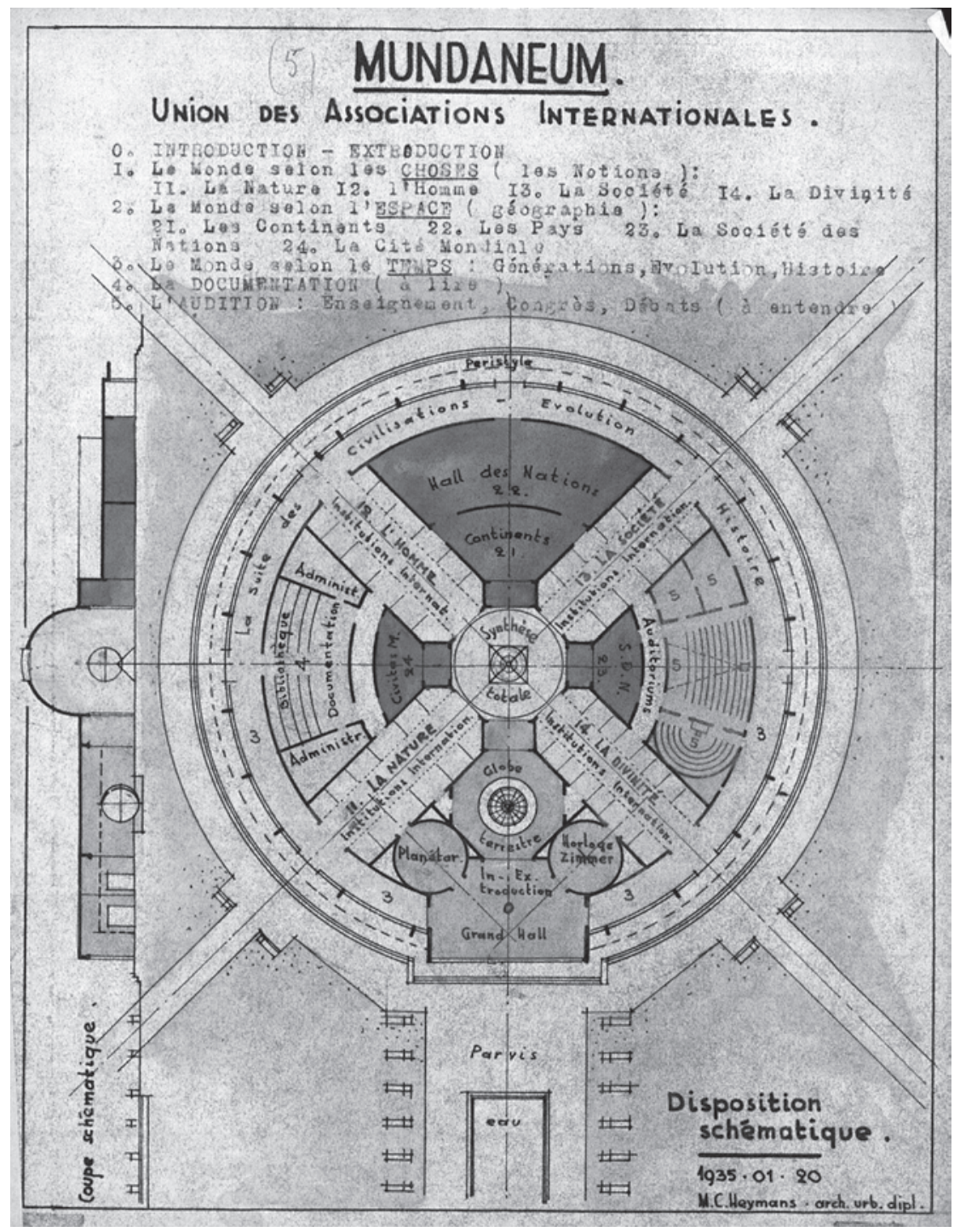

Figure 2. M. C. Heymans, Mundaneum. Schematic Layout (1935.01.20). (Archives of the Mundaneum, Personal Files of Paul Otlet [MDN], Fonds EUM [EUM], folder EUM III Mundaneum, 2 Mundaneum, 2A Généralité 10, document No. 8295.)

divinity). The perspective of the building (fig. 4) shows how Heymans positioned an international university building (12) and library (13) as two sphinxes in front of his modernist temple of knowledge, as such guarding the collections of the museum (11). A forecourt between the library and the university provided the main entrance for the visitor, with 
a drop-off zone for cars underneath the broad stairway. The stairs led to the entrance hall on the first floor, again with a planetarium on the left and a "horloge zimmer" on the right, and a globe in the middle of the room. The visitor who walked straight ahead entered the central hall of the building, the "Pantheon of Thought," which contained the Sacrarium ( situated under the central cupola of the main building in fig. 3). ${ }^{7}$ From here the visitor could either turn left into the section "World according to Space," which had different rooms allocated to the different countries, or turn right into the section "World according to Time," which ran through the history of the world. On the third floor, the "World according to Things" was exhibited, organized around four zones (Nature, Man, Society, Divinity). Four roof terraces were inserted between the courtyards in the four corners (see fig. 3). The galleries around these courtyards and terraces were devoted to either knowledge, applied knowledge (action), or art.

In this design, Heymans sought to achieve the right balance between a "temple" and a "permanent cerebral ( \pm materialist) instrument"; in other words, between esoteric symbolism and functionalist modernism. ${ }^{8}$ Through architectural features such as the long promenades, monumental staircases, large white walls, glass surfaces, and a frieze with bas reliefs, he gave the building a monumental functionalist appearance. But at the same time, the different "functional and expressive forms (in the antique way)" that he inserted "objectively" aimed to hold the visitors "spellbound," not by offering a view on a "beautiful" monument but by inciting reflection. Both the sequence and form of the spaces were charged with symbolic and often occult meaning. "As such, the Mundaneum," Heymans wrote, "is a conflict between utility and symbolism. The provision of each measure is only useful if it helps (psychologically) to a better comprehension of the things that are to be expressed." ${ }^{9}$ Like Le Corbusier, he used, or better, abused-if judged from the position of the German-Russian modernist avant-garde-the literalist language of modernist functionalism, which is connected to a materialist worldview, to express an occultist worldview in symbolic terms. In the next section, I will go deeper into this occult conception of order. For this, I will use a second design of a Mundaneum by Heymans.

\section{The Second Mundaneum Design of Maurice Heymans}

In July 1935, Heymans wrote to Otlet to tell him he suffered from burnout and had been compelled to rest: "I could not stop thinking though. Especially about the Mundaneum. Attached is a sketch of a new division of the groups. It is perhaps less "monumental" in the sense currently used, but I think that it is more simple, more pure, offering at least the same advantages. I put forward the proposal for you to meditate upon."10 


\section{MUNI) I NEU M 1}

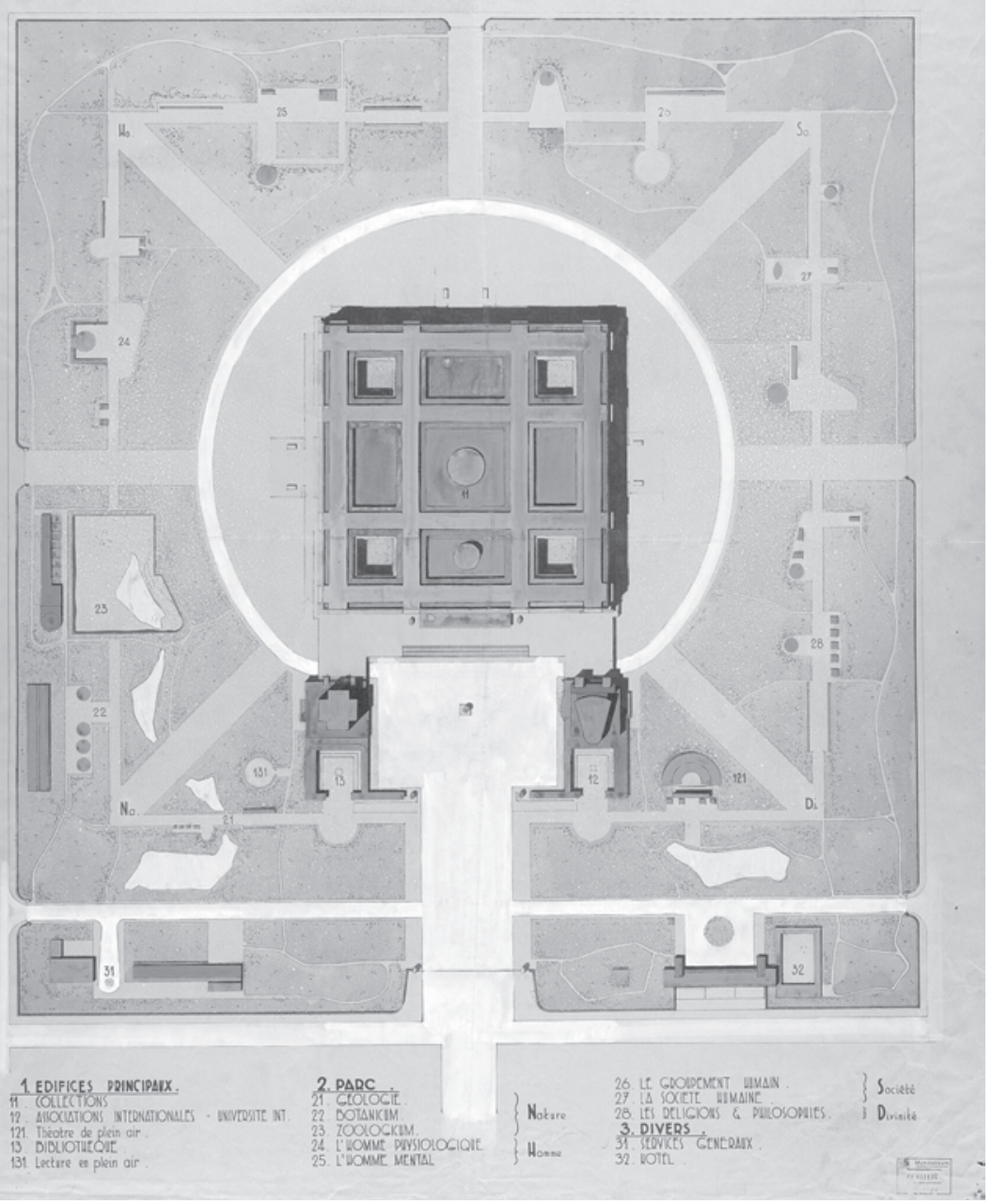

Figure 3. M. C. Heymans, Mundaneum 1. Comprehensive Plan (1935.03.15). (MDN, fonds Affiches [AFF], document No. 00 011147.)

Two preliminary sketches show how he had decomposed and complexified the first Mundaneum design and how he imagined a complete city around the central museum-library-university. Around the Mundaneum complex, there now were a documentation center, office buildings for international associations, plots for national pavilions, residential blocks, studios, a sport center, a train station, and a park (with a geological, 


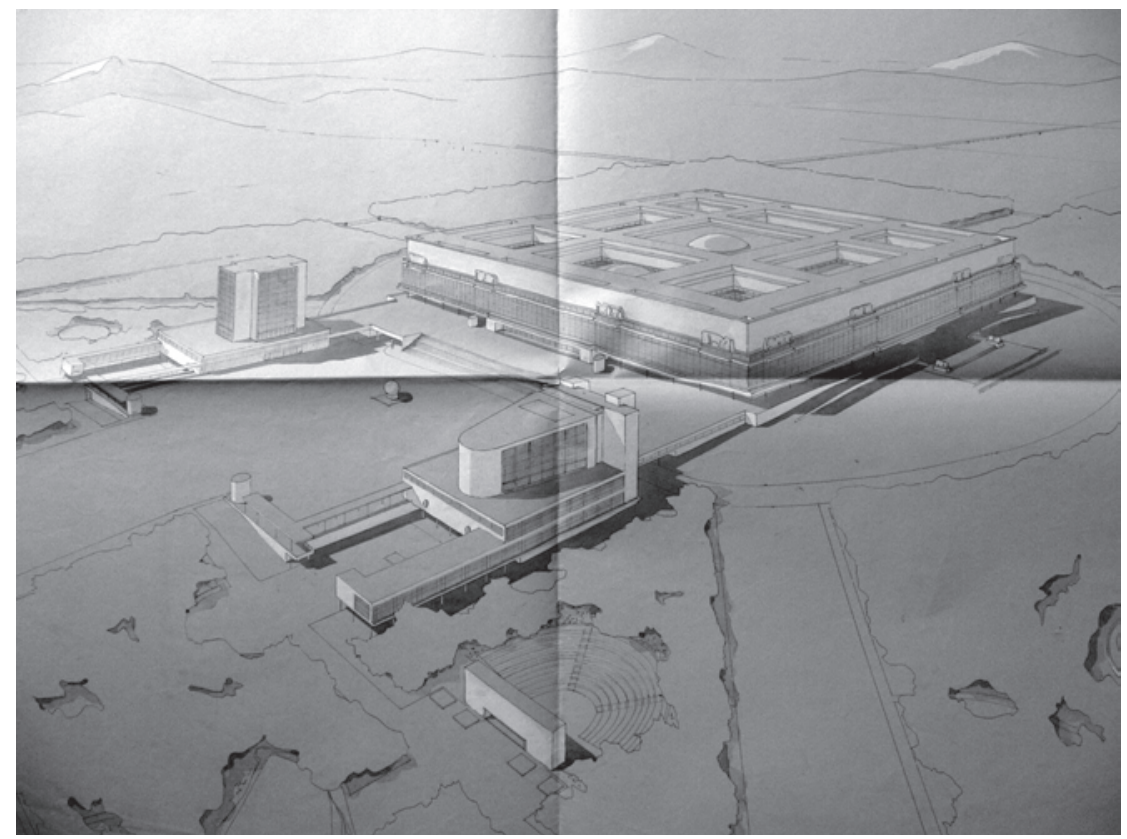

Figure 4. M. C. Heymans, Perspective of the Mundaneum. (1935.03.15). (MDN, AFF, document No. 00 011135.)

botanical and zoological centre). By October 1935, Heymans had turned the sketches into a second, highly detailed version of the Mundaneum, now centered in a Cité Mondiale or, as he called it, a "Cosmopolis" or "Mundaneis"- the Mundaneum as a polis.

The second design of the Mundaneum was more precise than the first design in its translation of Otlet's metaphysics in that it made visible the "architecture" of the book Monde (1935a) (see fig. 5). While in Traité de Documentation (1934), Otlet had summarized his ideas about documentation or the organization of knowledge as represented in a new highly elaborated conception of the nature of documents, in Monde he presented his theory of universalism or "mondialism" that provided the philosophical foundation for the internationalist activism that absorbed much of his life. Monde is a cosmological treatise that reflects in a grandiloquent, erudite, and often dull inventorial style seven metaphysical categories of being. It is these seven categories that Maurice Heymans visualized metaphorically through architectural spaces of various kinds.

The pyramid at the center exposed the first and largest chapter of Monde: "Le Monde selon les Choses" (see fig. 6). The four steps of the pyramid (allocated to the elements of Nature, Man, Society, and Divinity) progressed, as Heymans noted, as a "Tower of Babel," expressing "the 


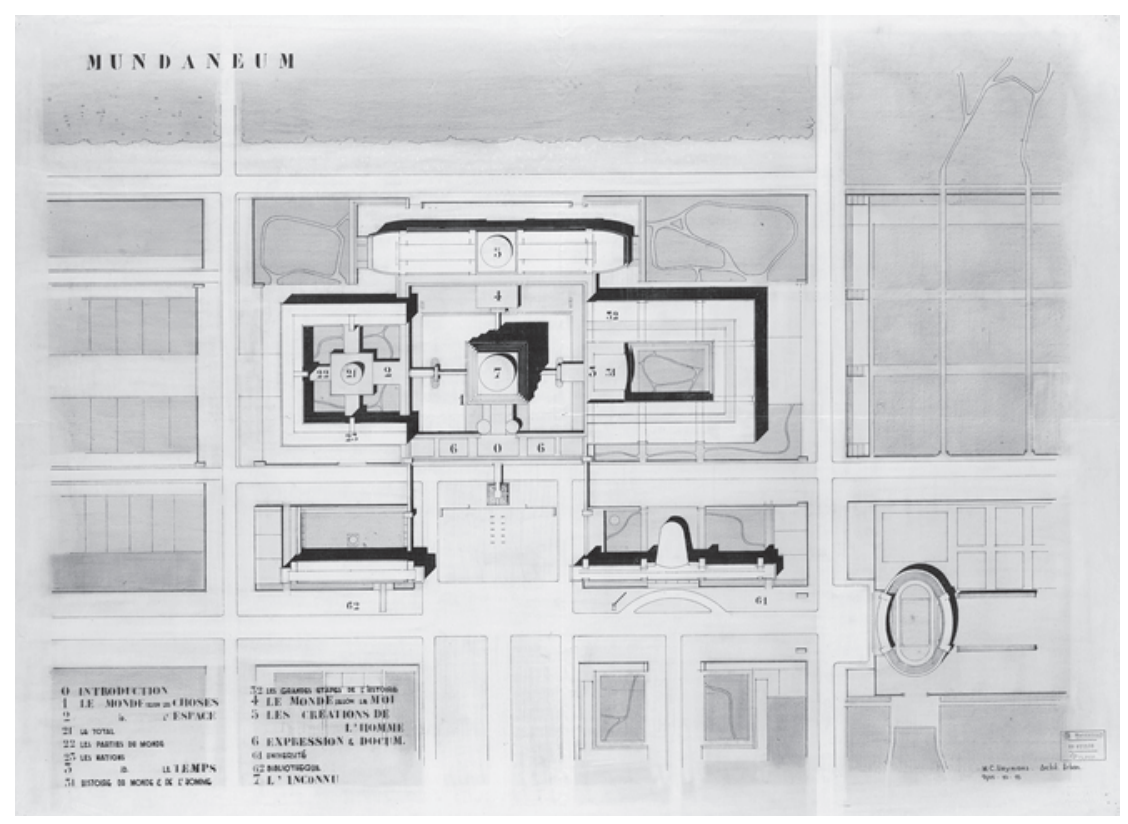

Figure 5. M. C. Heymans, Plan of the Mundaneum (1935.10.15). (MDN, AFF, document No. 00 011139.)

conquest of heaven" by Man through science. It was crowned by a cupola symbolizing the "Unknown" or the "ultimate finality" of things, corresponding to chapter 7 of Monde. The two U-shaped buildings on the left and right of the pyramid were to provide information about the world considered in its spatial and temporal dimension, respectively (chapters 2 and 3 of Monde). Behind the pyramid was a small hall devoted to "the World according to the Self" ["le Moi"] (chapter 4 of Monde), which gave access to a longitudinal building devoted to the "Creations of Man" (chapter 5 of Monde). A hall in front of the pyramid, plus the university and the library, represented the theme that had been described in the sixth chapter of Monde: "Expression and Documentation." In all these different parts of the building, concrete plans visualize a system of thought. Architecture here represents architectonics.

Following Heymans's second Mundaneum design, Otlet started to elaborate in 1936 a set of schemas under the title Atlas Monde, which translated graphically and spatially the structure and the content of his book Monde. The principal part of the atlas consists of a series of seven plates, in each of which a great circle is shown that is divided into sections that are filled with images borrowed mostly from traditional iconography but also with newly created abstract figures. Each circle illustrates one of 


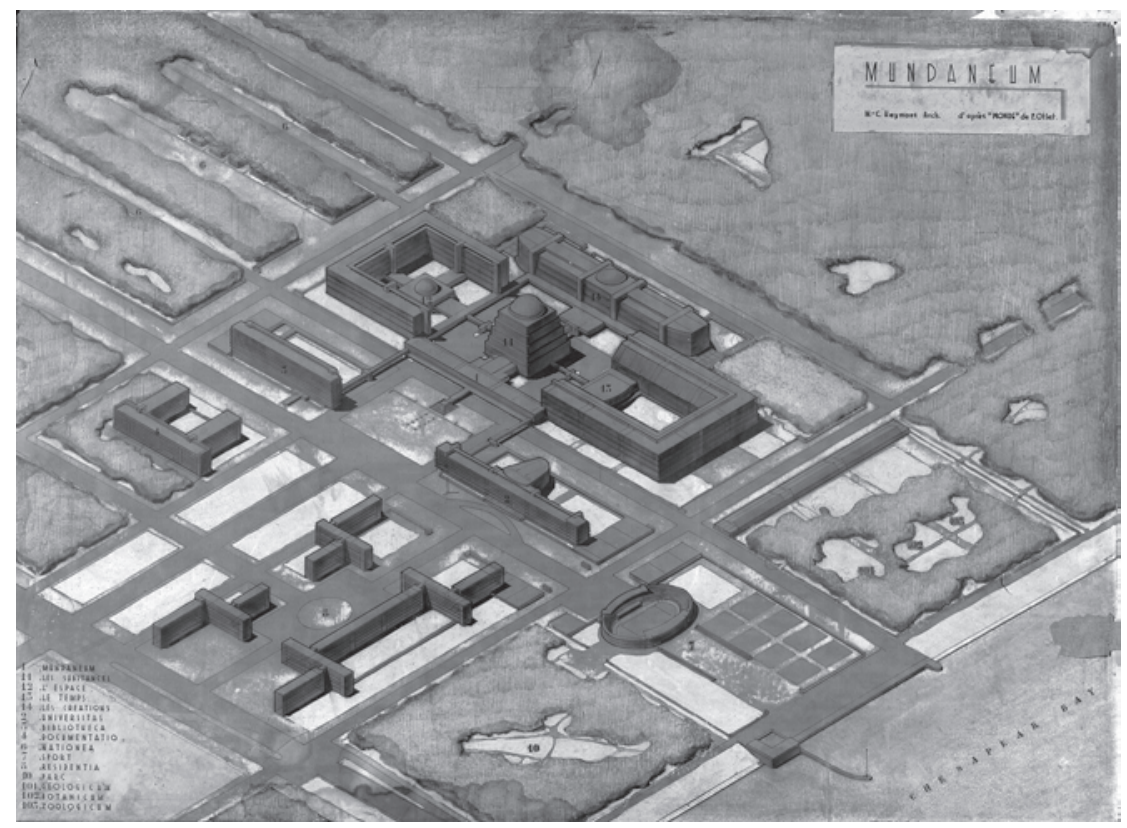

Figure 6. M. C. Heymans, Perspective of the Mundaneum (1935). (MDN, AFF.)

the seven metaphysical categories in his book Monde (1935a). Analogous to geography, Otlet imagined each circle to be a "map" of a particular "territory" of knowledge:

What would our notion of geography be if we did not dispose of maps to fix the facts? If we did not have Atlases which showed in a collection of maps the entire surface of the Earth; a proper coordinate system to fix the position of each group or point (meridians and parallels)? The series of pictures that are shown here tries to cover, like maps and atlases, the entire Universe considered from the viewpoint of the different sciences. It is, above all, an enumeration of what exists; a categorized and concatenated inventory, through which by intuitive generalization, the development of certain great laws of existence emerge. ${ }^{11}$

The series of seven circles are considered by Otlet to be "a first effort to give a visible expression to the entirely general unity of the World." 12 The seven circles were imagined to form together a sort of "world map" that covers the entire "globe" of knowledge, an idea that he illustrated in the schema "Sphere of the World." Otlet added an eighth circle in his atlas, which illustrated the Pyramid of the Mundaneum, the instrument or institution responsible for mapping the World of knowledge.

The Atlas Monde finishes with an image of the Cellula Mundaneum, or what Otlet conceived to be "a sort of Sacrarium" located at the core of 
the pyramidal edifice of the Mundaneum ${ }^{13}$ (see fig. 7). The Cellula Mundaneum represents the idea of a "synthesis of the World" in the form of an octagonal room where the eight circles of the Atlas Monde are shown in fresco on the walls, surrounded by shelves of books and other smaller pictures. ${ }^{14}$ At the center of the room, the eight circles are reproduced on the floor in a circular formation, in the middle of which stands a sculptural representation of the synthesis of syntheses: the sphere "Mundus" supported by the pyramid "Mundaneum."

The Sacrarium, or Cellula Mundaneum, is the end point of what the Mundaneum and the Atlas Monde aimed to achieve: a complete synthesis of knowledge. It seems that the model of encyclopedic synthesis as expressed in the drawings of Heymans and Otlet can be retraced to three different spheres of influence: Platonism, positivism, and occultism. First, the use of the pyramid as the symbol for the Mundaneum (and used as the central building in Heymans's Mundaneum) seems to correspond to the pyramidal model of platonic encyclopedism. In the platonic model, the notion of the encyclopedia referred to the idea that if an individual had completed the path that runs the full circle of the disciplines, he or she was fully educated to engage with the subject of philosophy, which uses all the other disciplines to arrive at an overview of knowledge. In such a platonic model, the full content of the circles of the disciplines is not the ultimate goal but rather the path itself that leads to having a sense of the whole (Morreel, 2006). One can only acquire this sense of the whole if the passage from plurality to unity is completed. This reduction from the many to the one can be achieved, according to Plato, through the method of a dialectic between analysis and synthesis. The analyticalsynthetic method reduces a mass of knowledge to a set of principles. Dialectics opens the path to the ultimate stage, which is the perception of the unity of all disciplines. This platonic model of encyclopaedism is pyramidal: at the basis there is the mass of phenomena, and at the apex there is a metaphysical understanding of Being. Knowledge must be attained individually by walking the path through the encyclopedic circle. The trajectory through Heymans's Mundaneum and through the circles in the Atlas Monde may be interpreted as such a "path" that brings the individual reader to a philosophical panorama (the top of the Pyramid of the Mundaneum) from where the unity of knowledge can be grasped (Sphere of the World).

Second, the configuration of the Mundaneum and the Atlas Monde evokes the notion of "synthesis" that was central to the nineteenth-century theory of positivism, which incorporated to a certain extent this platonic model of encyclopedism. As Pierre Laffitte, the principal spokesman of French positivism after Auguste Comte's death, summarized concisely, positivism was 


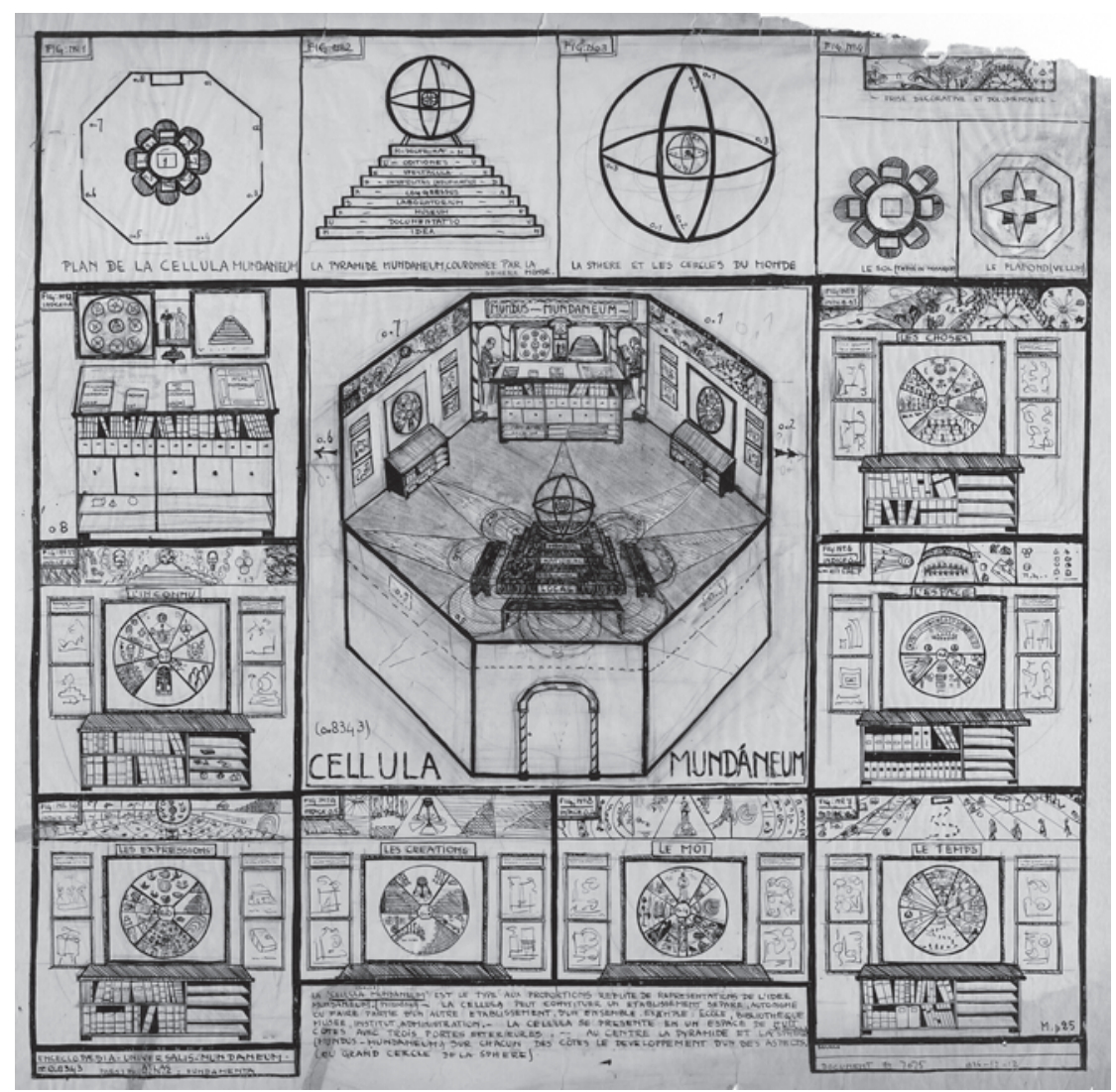

Figure 7. Paul Otlet, Cellula Mundaneum (1936). (MDN, AFF. (C) Mundaneum.)

a general doctrine providing common and universal rules for the direction of the world, man and society, . . . a doctrine which comprehends all that it is given to us to know, and which in its totality contains parts so well connected and so consonant with each other, and so complete, that nothing is left to chance, no problem is left without solution, and everyone knows in all circumstances what he must think..$^{15}$ (as reproduced in Simon, 1963, p. 45)

Many positivists, who were inspired by the work of Comte, aspired to a synthetic and comprehensive view of the universe. Most important was the British positivist Herbert Spencer, who presented an all-embracing view of the domains of the universe in his "Synthetic Philosophy," which we know Otlet anxiously read (Rayward, 1975, pp. 26-27). Like these positivists, Otlet's Atlas Monde and Heymans's Mundaneum give an almost inventorial 
cosmological summary of the elements that constitute the world, of which the comprehensiveness is even further accentuated by including, after the British positivist Herbert Spencer, the category of the "Unknowable" (Turner, 2000, p. 35). Despite the aspiration to completeness, Otlet, in an agnostic manner, did not exclude religion, like Spencer, as a way for man to relate to what is unknown or unseen.

In its quasi-religious tone, the schematic figures in Celulla Mundaneum seem to build on Spencer's notion of synthesis. According to Spencer, science is "partially-unified knowledge," and the work of philosophy is to synthesize or to abstract the general principles from science so as to arrive at "completely-unified knowledge" (Harré, 2003, p. 25). Accordingly, Spencer devoted his life to what he considered the most important task of philosophy: the creation of a general synthetic philosophical system that he founded on the basis of the law of evolution as abstracted from chemistry, biology, and human history. It is the same notion of synthesis, in the sense of an amalgamation of separate disciplines to produce a united theory, that we find in Otlet's thinking. Otlet considered synthesis to be an evolutionary process of generalization and integration of knowledge, paralleling the increasing specialization and complexity of knowledge. Furthermore, Otlet seems to charge the scientific synthesis in the image Cellula Mundaneum with a quasi-religious meaning, as Spencer did in his First Principles (1862). In First Principles, Spencer explained how all knowledge is based on the organization of particular facts in abstract classes of facts, and the integration of these classes of facts in even greater classes (Becquemont \& Mucchielli, 1998, pp. 112-115). However, the most general truths do not allow interpretation because they cannot be included in a more general truth. Spencer assumed that the absolute was unknowable, although it did exist as a mode of consciousness. It is in that sense that Spencer thought that science and religion were complementary. Science and religion both explain the same reality but from different sides: science from close by and on the basis of what is visible, and religion from afar and on the basis of what is invisible. Spencer attempted to reconcile science and religion in that he showed that ultimate religious concepts and scientific ideas (such as matter, space, and time) both represent realities of which we are conscious but that lie beyond rational comprehension. The general categories that Otlet represents in the seven circles of the Atlas Monde are precisely such ultimate scientific concepts. They are intuitive generalizations of what lies beyond the comprehension of science but of what is, nonetheless, in a quasi-religious way believed to be real.

Third, the synthetic encyclopedism that marks the Atlas Monde and the Mundaneum has a scientistic religious tenor that reveals the influence of various forms of occultism. As in various forms of occult spirituality, secret knowledge about the world is revealed through initiation into the 
meaning of abstract or concrete symbols. Given Otlet's familiarity with theosophy and other occult societies through Henri La Fontaine and the idealist painter Jean Delville, the iconography of the circles seems to draw especially on the symbolism that were central in the teachings of theosophist leaders such as Helena Blavastky (1831-1891), Annie Besant (1847-1933), and Charles W. Leadbeater (1847-1934). Theosophist iconography absorbed its esoteric symbolism from a mixture of Western occult traditions, nineteenth-century American spiritualism, and oriental religions and placed these within an evolutionary framework that was derived from both contemporary scientific evolution and Indian concepts of cosmic cycles (Tuchman et al., 1986, p. 388). Otlet's circles of the Atlas Monde and the trajectory through the Mundaneum initiate its reader/visitor into quasi-religious universal truths in the same way as in, for example, cabalistic forms of mediation (inner magic) where on the basis of the Sefirot (the ten qualities of God), depicted in a "Tree of Life" pattern, the meditating soul is guided back to its home in the Godhead; or in Hinduism and Buddhism, where Mandala's (Sanskrit for "round" or "circle") or circular spiritual diagrams of the universe are used to assist concentration and meditation.

\section{A Mundaneum Liturgy: Heymans's Visualization of the "Network Mundaneum"}

In 1938, Heymans made a third set of drawings to visualize Otlet's changed conception of the Mundaneum as a centralized institutional network. Again, the idea of synthesis, as discussed in the previous section, proved to be of central importance but took a different form.

"The Mundaneum is a network," Otlet wrote in Monde (1935a). "The institution defined as such should be thought of as the multiplication and organization over the Earth of a chain of similar institutions on different scales and for different purposes, ultimately spreading over all places and for all specializations" (p. 452). The Mundaneum was now conceived as a network that gathered all knowledge about the world society into a "central Mundaneum, into a point on the Globe [where] the reflection and total meaning of the World will exist" (p. 452).

This changed conception of the Mundaneum built on the idea of the Urbaneum and Belganeum that Otlet had launched earlier. In 1928, in the same year when he elaborated the plans for the Mundaneum in Geneva with Le Corbusier, Otlet had proposed another of his neologisms; the "Urbanarium," a "scientific and didactic" demonstration on the structure and functions of urbanism (1928a, p. 496; 1931, p. 124). He also spoke about the idea to construct for the occasion of the centenary of the Belgian national independence in 1930 a permanent building "devoted to making known the main things about 'Belgium in the World'" (1928b, p. 662). In 1931, these two concepts were further elaborated. 
In that year Victor Bourgeois made plans for an Urbaneum, and at the same time, Otlet continued to promote the conception of "a building for 'Belgium in the world' or 'Belganeum." "16 In his Plan Belgique, Otlet defined the "Belganeum" or, more generally, the "Nationeum" as an institution that would assemble data on Belgium and the Belgians, analyze and synthesize these data, and "subsequently 'visualize' them by means of representations" (1935b, p. 156). With the elaboration of the concept of the Belganeum or, more broadly, the Nationeum, the trinity UrbaneumNationeum-Mundaneum was born in Otlet's imagination. On some occasions, Otlet also added the Regioneum or the Brabanteneum as a piece to the jigsaw puzzle. For each spatial scale, Otlet had conceived a type of observation tower; each was equipped with the lens appropriate to capture its different geographical area. For the Urbaneum, Regioneum, Nationeum, and Mundaneum, the goals and instruments would stay the same, but each of these different types of "towers" would help the next institutional level to see farther, to extend its horizon.

Otlet's concept of the Mundaneum Network was indebted to the sociologist and leading member of the Vienna Circle of logical positivists, Otto Neurath (1882-1945). In relation to a possible collaborative project on a visual atlas, Otlet and Neurath speculated in the early 1930s about building mobile museums and networks of museums (Vossoughian, 2004; Van Acker, 2011). In 1931, Neurath stated that "to speak of the museum of the future is like speaking of the automobile of the future. Automobiles are manufactured in series and not produced one by one in a smithy." In the future, museums will be manufactured, exactly as books are today, Otlet and Neurath believed (Neurath, 1933, p. 458). Seeking a practical realization of the idea, Neurath and Otlet negotiated with a handful of people to become part of the "Mundaneum chain." Within such a network of "Institutions-Museums" or "chambres-musées" (museum-rooms), a "Mundaneum exhibition" could then be kept in a permanent state of mobility, travelling from country to country while perfecting and enriching itself by borrowing from several collections. ${ }^{17}$ A good "Mundaneumtactics," according to Neurath, was "that wherever it is possible, we must try to convince municipal local museums, school museums, social museums, country and royal museums to host a Mundaneum section."18

Otlet called on Heymans in 1938 to give architectural expression to this changed conception of the Mundaneum. For each scale, Heymans designed a Mundaneum prototype: an Urbaneum for the local scale (see fig. 8), a Regioneum for the regional scale, a Nationeum for the national scale, a Continentaneum for the continental scale, an Internationeum for the international scale, and a Mundaneum for the global scale. He illustrated each of them with a perspective drawing and a schematic plan. Heymans further stretched the range of scales by designing a "Civitas Mundaneum" and "Domus Mundaneum." The "Civitas Mundaneum" (see fig. 9) 


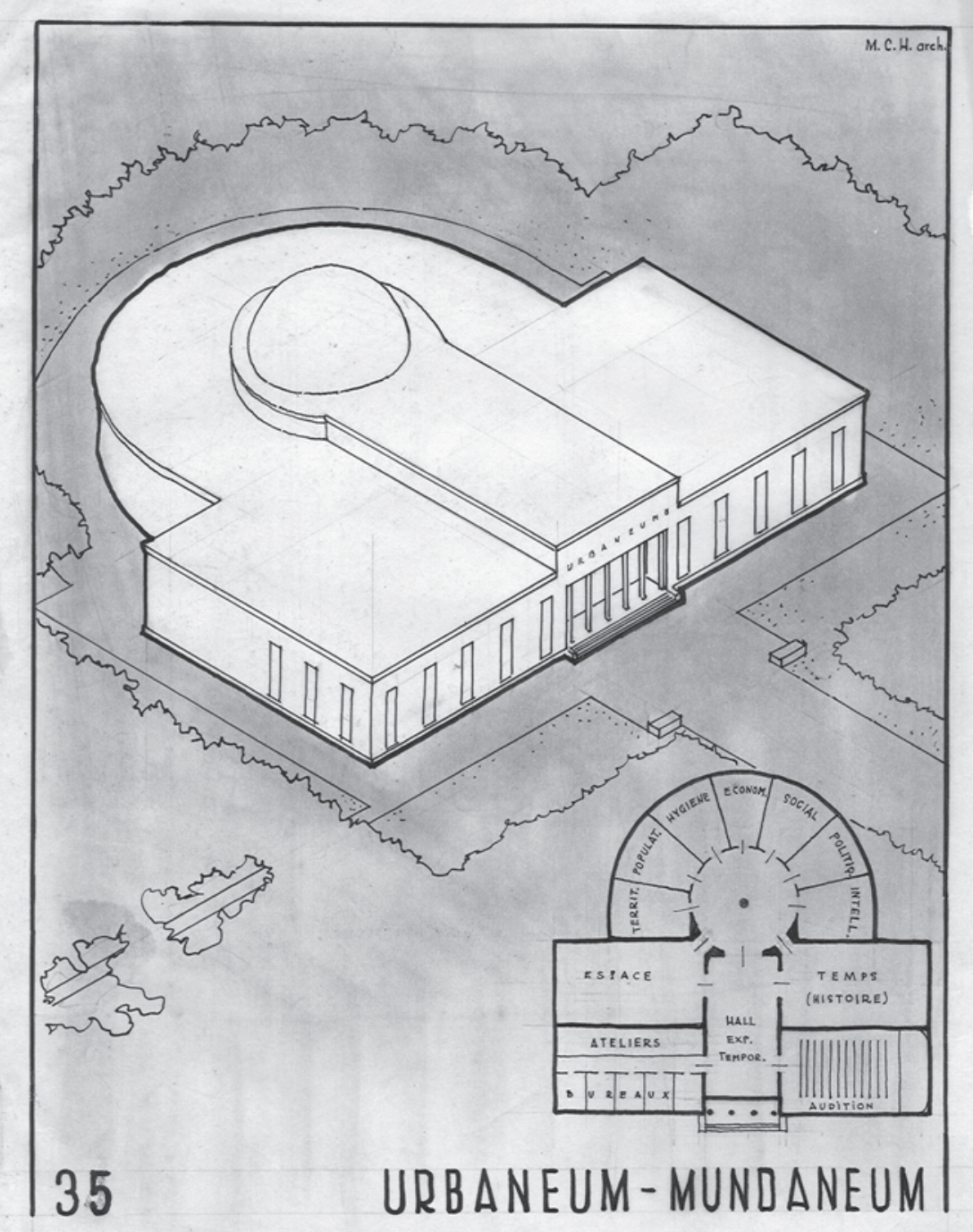

Figure 8. Maurice Heymans, Urbaneum - Mundaneum (1938). (MDN, fonds Amis du Palais Mondial [APM], box APM OP 23.)

or Cité Mondiale was intended to be, as Otlet had described in Monde, "a sort of amplification of the principal Mundaneum, and which could, by means of the given Network, help to develop and maintain the other affiliated institutions" (1935a, p. 452). The "Domus Mundaneum" (see fig. 10), in contrast, was intended to be one of a whole series of instruments for 


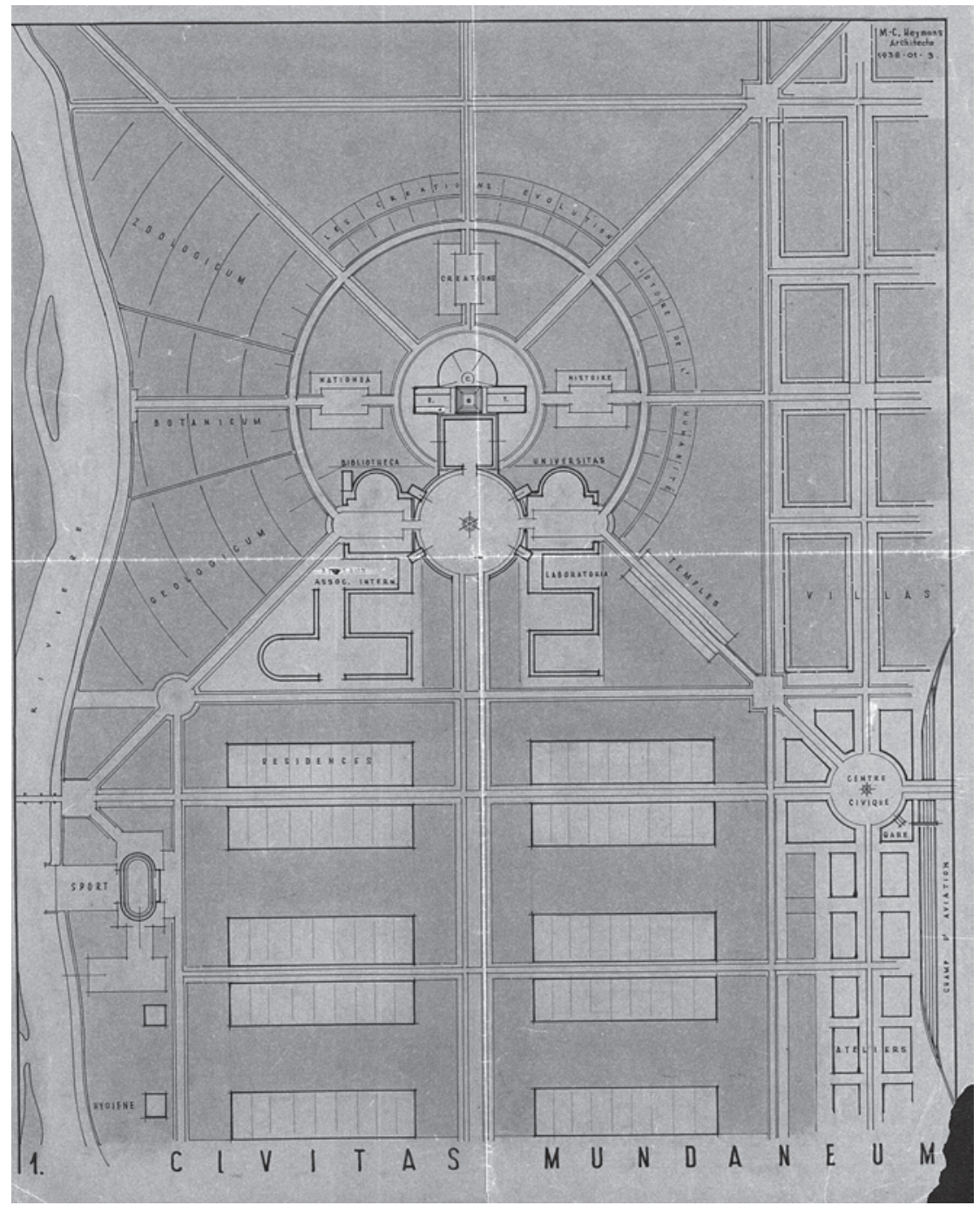

Figure 9. M. Heymans, Civitas Mundaneum (1938). (MDN, EUM 10.)

helping the individual person to participate in the organization of knowledge. These "species" of the Network Mudaneum, as Otlet called them, are represented in figure 11. They are instruments to facilitate the transmission of knowledge, but they also seem to be meant as instruments to be used in a quasi-religious cosmopolitan liturgy. Like the institutional network of the Catholic Church controlled by the Vatican, the Network Mundaneum would also be a network of mission stations controlled by 


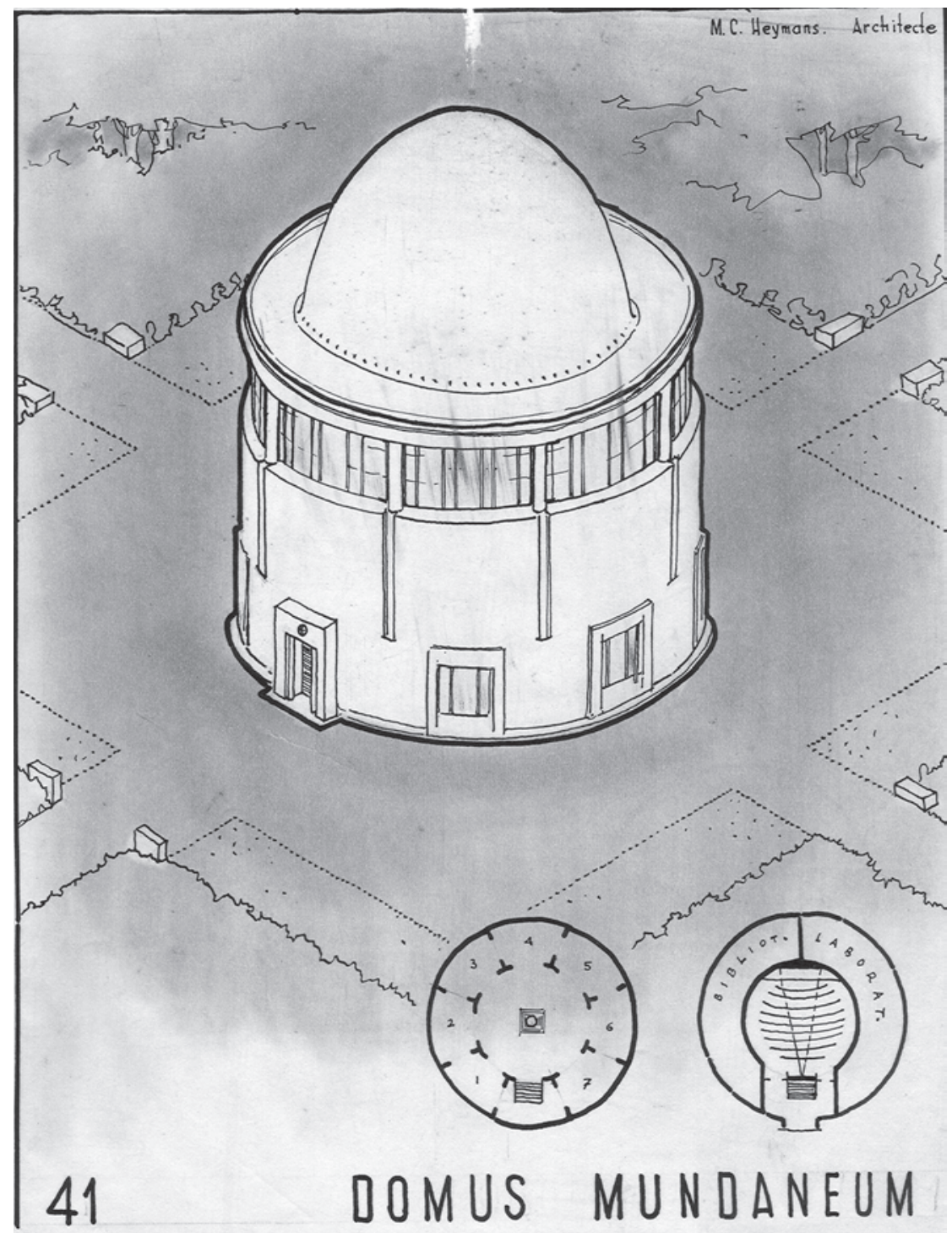

Figure 10. M. Heymans, Domus Mundaneum (1938). (MDN, APM, APM OP 23.) 


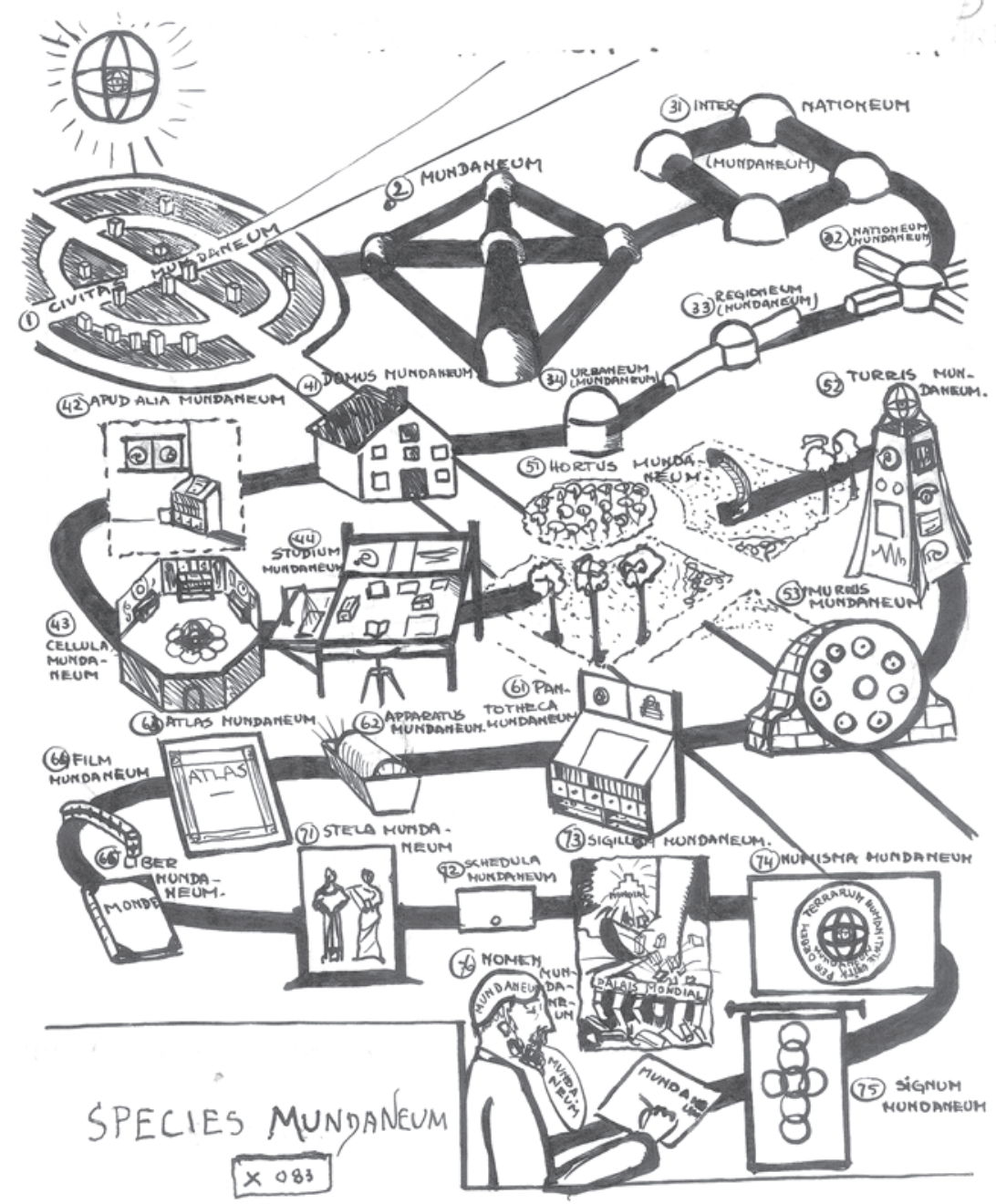

Figure 11. Paul Otlet, Species Mundaneum. (MDN, EUM, document No. 8506 (C) Mundaneum.)

the Cité Mondiale (and its secular church-the Mundaneum), equipped with and distributing quasi-ceremonial objects of universal knowledge, spreading the "universal spirit," and asking each person "to place the global and universal idea at the basis of one's own life, business, jobs, individual, domestic, friendly aspirations. It is proposed that one organize one's own study and documentation according to the universal methods, and connect them as a post or station to the Universal Network" (Otlet, 1935a, p. 454). 


\section{Conclusion: Memory Theatre as Utopia}

In the footsteps of Le Corbusier, Heymans created a complex architectural metaphor for the Mundaneum as a centre of initiation into synthesized knowledge. The Mundaneum is represented as the center of the world that provides privileged access to the universal spirit of knowledge; it is the place where humanity has an overview and therefore becomes conscious of its own thought. As if it were a late descendant of Hegel's view of the collective human spirit that actualizes itself through gradual self-comprehension, the Mundaneum is evoked as the center that brings together spirit and humanity, thought and life itself. The Mundaneum with its Sacrarium is expressed as a sacred, profane, modernist temple where that transcendental and supranational substance, called "spirit," "culturem," or "intellect" is accumulated for the sake of the advancement of society. Spirit is, according to Derrida, what "comes before and in front, what anticipates and questions before all else" (1989, p. 43). By claiming to possess the spirit of the world, the Mundaneum sets itself the mission to become the leading point of memory and decision making. It is this deeper understanding of the Mundaneum as a center where knowledge is brought to a synthesis for the sake of social renewal that Heymans had grasped and brought metaphorically to expression through architecture.

Heymans's elaboration of that complex metaphor relied on two modes of figurative thought that function on the basis of the analogy between knowledge organization and spatial organization: the art of memory and utopia. In the art of memory, a set of topics or items of knowledge are associated with and inscribed in the "loci" of an imagined theatre of memory or a sequence of spaces (Yates, 1966; Rossi, 2000). Utopia, on the other hand, imagines a new scheme of social order in the form of an urban or architectural constellation, often geometrical and well-planned cities. Whereas the ars memoriae supports the organization of acquired knowledge, utopia facilitates the organization and anticipation of the future. Heymans's designs of the Mundaneum took the form of a modernist theatre of memory to visualize Otlet's cosmological and espistemological order, while at the same time these designs concretized the utopian dimension of the Mundaneum as a set of institutions that leans on organized and acquired knowledge to anticipate the future and to advance social organization.

These two modes of analogical reasoning (the art of memory and utopia) that Heymans applied architecturally were, however, already present in and probably derived from the drawings made by Otlet. In his autobiographic notes, Otlet noted that "I find that I must draw certain ideas, certain graphics. And it is in my mind that I make the movements that draw: a circle, a triangle, a line" (Levie, 2006, p. 281). We could call the process that Otlet describes in this passage, after Rudolf Arnheim, a process of "visual thinking" (Arnheim, 1969). Visual thinking involves how we organize mental images using shape, line, color, and composition to make 
them meaningful (Trumbo, 2006, p. 269). It is by means of such a process of visual thinking that Otlet fleshed out particular concepts or thoughts by means of schematic sketches such as of the pyramid, the globe, or the network (van den Heuvel, 2008). By drawing these spatial structures, Otlet was plasticizing the "art of memory" in the sense of an art of invention or a method of associational discovery, while at the same time it allowed him to enter in a utopian form of reflection in the sense of a mode of ideal thinking that operates through projective and anticipatory imagination (Ricoeur, 1994, p. 124).

\section{Notes}

1. There is no biography available of Maurice Heymans, "Lorsqu" un urbaniste devient architecte. A brief overview of his career is described in: Anonymous. (1959). Maurice Heymans. Vingt années d'activité soutenue. La Maison, 15 (11), 372.

2. Giuliano Gresleri and Marcello Fagiolo both make this comparison (Fagiolo, 1978; Gresleri \& Matteoni, 1982). Le Corbusier refers to the Khorsabad complex in Le Corbusier, 1994, p. 80.

3. Teige, K. (1929). Mundaneum. Stavba, 7 (10). Reproduced in Hays, 1974, pp. 585-614.

4. Cited from Le Corbusier's In Defense of Architecture from 1933. Reproduced in Hays, 1974, p. 608.

5. Letter from Maurice Heymans to Paul Otlet, Letter to Paul Otlet (1934.10.16). Archives of the Mundaneum (Mons), Fonds Cité Mondiale, Box 8, Correspondance Architectes, Folder Heymans.

6. This description is found in a sketch from Maurice Heymans, dated 7 January 1935. Archives of the Mundaneum (Mons), Fonds Cité Mondiale, Box 8, Correspondence Architectes, Folder Heymans.

7. Sketch from Maurice Heymans, dated 25 February 1935. Archives of the Mundaneum (Mons), Fonds Cité Mondiale, Box 8, Correspondence Architectes, Folder Heymans.

8. Maurice Heymans, Note (1935.01.15). MDN, CM, Box 8, Correspondence Architecte, Folder Heymans.

9. Maurice Heymans, Sketch of the Mundaneum (1935.01.01) Archives of the Mundaneum (Mons), Fonds Cité Mondiale, Box 8, Correspondance Architectes, folder Heymans.

10. Maurice Heymans in a letter to Paul Otlet, dated 19 July 1935 . Archives of the Mundaneum (Mons), Fonds Cité Mondiale, Box 8, Correspondence Architectes, Folder Heymans.

11 Quoted from a document "Final Observations" written by Paul Otlet. Archives of the Mundaneum (Mons), Fonds Affiches, Atlas Monde, Document No. 7092.

12. Ibid.

13. Quoted from a document written by Paul Otlet called "Le Mundananeum." Archives of the Mundaneum (Mons), Fonds Affiches, Atlas Monde, Document No. 7093.

14. Quoted from a document "Cellula Mundaneum 083.43" written by Paul Otlet. Archives of the Mundaneum (Mons), Fonds Affiches, Atlas Monde, Document No. 7094.

15. Orginal quote : Pierre Laffitte (1875) Les grands types de l'humanité: appréciation systématique des principaux agents de l'évolution humaine. Vol.1. Paris: Ernest Leroux. p. 6-7.

16. Note of Paul Otlet, Le Plan National de la Belgique_Le Plan Intellectuel. Avant Projet_Rapport de Paul Otlet (Première Rédaction), dated 31 October 1931. Archives of the Mundaneum (Mons), Fonds Notes Numerotés, Note $n^{\circ} 6553$.

17. Letter of Paul Otlet to Otto Neurath, dated 27 June 1930. Archives of the Mundaneum (Mons), Fonds EUM, Box 1, Farde 4. Orbis Encyclopaedia Synthetica.

18. Letter of Otto Neurath to Paul Otlet, dated 25 October 1929. Archives of the Mundaneum (Mons), Fonds EUM, Box 1, Farde 4. Orbis Encyclopaedia Synthetica.

\section{REFERENCES}

Arnheim, R. (1969). Visual thinking. Berkeley: University of California Press.

Aron, J. (1982). La Cambre et l'architecture: Un regard sur le Bauhaus belge. Brussels, Belgium: Mardaga. 
Bourgeois, V. (1933). Le Concours International pour l'Urbanisation de la Rive gauche de l'Escaut, à Anvers. La Cité, 11(8), 145-168.

Becquemont, D., \& Mucchielli, L. (1998) Le cas Spencer. Religion, science et politique. Paris: Presses Universitaires de France.

Courtiau, C. (1987). La Cité Internationale, 1927-1931. In I. Charollais \& A. Ducret (Eds.), Le Corbusier à Genève 1922-1932. Projets et réalisations (pp. 53-69). Lausanne, Switzerland: Éditions Payot.

Derrida, J. (1989). Of spirit: Heidegger and the question. Chicago: The University of Chicago Press.

Fagiolo, M. (1978). La nuova Babilonia secondo Le Corbusier. Ottagono, 13(48), 22-29.

Gresleri, G. and Matteoni, D. (1982). La Citta'Mondiale. Andersen, Hébrard, Otlet, Le Corbusier. Venice, Italy: Marsilio Editori.

Harré, R. (2003) Positivist thought in the nineteenth century. In T. Baldwin (Ed.), The Cambridge history of philosophy 1870-1945 (pp. 11-26). Cambridge, England: Cambridge University Press.

Hays K. M. (Ed.). (1974). Oppositions reader: Selected readings from a journal for ideas and criticism in architecture 1973-1984. New York: Princeton Architectural Press.

Heymans, M. (1933). Antwerpen linkeroever. Opbouwen, 3(17), 284-285.

Heymans, M. (1934). Urbanisme? L'Epoque, 2(4), 61-71.

Le Corbusier. (1994). Urbanisme. Paris: Flammarion. (Original work published 1925)

Le Corbusier. (1960). Précisions. Sun un état présent de l'architecture et de l'urbanisme. Paris: Éditions Vincent, Fréal \& Cie. (Original work published 1930)

Levie, F. (2006). L'homme qui voulait classer le monde: Paul Otlet et le Mundaneum. Brussels, Belgium: Les Impressions Nouvelles.

Lissitzky, E. (1928). Idole und idolverehrer. Bauindustrie, pp. 11-12. Reproduced in E. Lissitzky (1977), Proun und Wolkenbügel. Schriften, Briefe, Dokumente (pp. 41-54) Dresden, Germany: Verlag der Kunst Dresden).

Morreel, G. (2006) Circles in the sand. Utopian encyclopedism from antiquity to the Interwar period (1919-1939). Unpublished doctoral dissertation. Antwerp, Belgium: University of Antwerp.

Neurath, O. (1933). Museums of the future. Survey Graphic, 22(9), 458-463, 479, 484, 486.

Otlet, P. (1928a). Genève-Cité internationale. L'Administration Locale, 38-40, 492-497.

Otlet, P. (1928b). Les communes et le centenaire. Le Mouvement Communal, 98, 659-663.

Otlet, P. (1931). L'Urbaneum. La Cité, 9(10), 121-129.

Otlet, P. (1934). Sociologie et urbanisme. L'Époque, 2, 72-76, 81-92.

Otlet, P. (1934). Traité de documentation: le livre sur le livre, théorie et pratique. Brussels, Belgium: Editiones Mundaneum.

Otlet, P. (1935a). Monde. Essai d'Universalisme. Connaissance du monde, sentiment du monde, action organisée et plan du monde. Brussels, Belgium: Mundaneum.

Otlet, P. (1935b). Plan Belgique. Essai d’un plan général economique, social, culturel. Plan d'urbanisation national. Liaison avec le plan mondial. Conditions. Problèmes. Solutions. Réformes. Brussels, Belgium: Editiones Mundaneum/D. Van Keerberghen \& Fils.

Rayward, W. B. (1975). The universe of information. The work of Paul Otlet for documentation and international organisation. Moscow, Soviet Union: VINITI.

Rayward, W. B. (1997). The origins of information science and the International Institute of Bibliography/International Federation for Information and Documentation (FID). Journal of the American Society for Information Science, 48(4), 289-300.

Ricoeur, P. (1994). Imagination in discourse and in action. In G. Robinson \& J. F. Rundell (Eds.), Rethinking imagination: Culture and creativity (pp. 118-135). London: Routledge.

Rossi, P. (2000). Logic and the art of memory: The quest for a universal language. London: Athlone Press.

Simon, W. M. (1963). European positivism in the nineteenth century. An essay in intellectual history. Ithaca, NY: Cornell University Press.

Trumbo, J. (2006). Making science visible. Visual literacy in science communication. In L. Pauwels (Ed.), Visual cultures of science: Rethinking representational practices in knowledge building and science communication (pp. 266-283). Hanover, NH: University Press of New England.

Tuchman, M., Freeman, J., \& Blotkamp, C. (1986). The spiritual in art: Abstract painting 1890 1985. New York: Abbeville Press.

Turner, J. H. (2000). The origins of positivism: The contributions of Auguste Comte and Herbert Spencer. In G. Ritzer \& B. Smart (Eds.), Handbook of social theory (pp. 30-42). London: SAGE. 
Van Acker, W. (2011). Internationalist utopias of visual education: the graphic and scenographic transformation of the Universal Encyclopaedia in the work of Paul Otlet, Patrick Geddes and Otto Neurath. Perspectives on Science, 19(1), 32-80.

van den Heuvel, C. (2008). Building society, constructing knowledge, weaving the web: Otlet's visualizations of a global information society and his concept of a universal civilization. In W. B. Rayward (Ed.), European modernism and the information society: Informing the present, understanding the past (pp. 127-153). Aldershot, England: Ashgate.

Vossoughian, N. (2004). Facts and artifacts: Otto Neurath and the social science of socialization. Unpublished doctoral dissertation. New York: Columbia University.

Welsh, R. P. (1986). Sacred geometry: French symbolism and early abstraction. In M. Tuchman, J. Freeman, \& C. Blotkamp (Eds.), The Spiritual in art: Abstract painting 1890-1985 (pp. 63-87). New York: Abbeville Press.

Yates, F. A. (1966) The art of memory. London: Pimlico.

\section{Archival Sources}

Fondation Le Corbusier (FLC), Paris. Fonds Mundaneum and Cité Mondiale.

Mundaneum, Mons. Personal papers of Paul Otlet (MDN). Fonds Affiches (AFF), Fonds Encyclopaedia Universalis Mundaneum (EUM), Fonds Notes Numerotés, and Fonds Cité Mondiale.

Wouter Van Acker is a postdoctoral researcher at the Department of Architecture and Urban Planning at Ghent University. He earned his civil engineering/architecture degree from Ghent University in 2004. For his doctoral dissertation (PhD, civil engineering/architecture, Ghent University, 2011), he studied the visionary schemes and schemas of the Belgian internationalist and encyclopedist Paul Otlet (1868-1944). His current research focuses on the spatial organization, representation, and dissemination of information and knowledge in urban settings. 